\title{
Analysis of Green Open Space Needs in Surabaya City
}

\author{
Sri Murtini* \\ Geography Education Department \\ Faculty of Social Sciences and Law, \\ Universitas Negeri Surabaya \\ Surabaya, East Java, Indonesia \\ srimurtini@unesa.ac.id \\ Ita Mardiani Zain \\ Geography Education Department \\ Faculty of Social Sciences and Law, \\ Universitas Negeri Surabaya \\ Surabaya, East Java, Indonesia \\ itazain@unesa.ac.id
}

\author{
Agus Sutedjo \\ Geography Education Department \\ Faculty of Social Sciences and Law, \\ Universitas Negeri Surabaya \\ Surabaya, East Java, Indonesia \\ agussutedjo@unesa.ac.id \\ Alif Putra Lestari \\ Graduate Student of Geography \\ Education Department \\ Faculty of Social Sciences and Law, \\ Universitas Negeri Surabaya \\ Surabaya, East Java, Indonesia \\ alifputra@gmail.com
}

\author{
Bambang Hariyanto \\ Geography Education Department \\ Faculty of Social Sciences and Law, \\ Universitas Negeri Surabaya \\ Surabaya, East Java, Indonesia \\ bambanghariyanto@unesa.ac.id
}

\begin{abstract}
The more population growth in the city of Surabaya will affect the need for green open space (GOS). The research objectives are: 1). Mapping green space by identifying the type and classification of green space, 2), analyzing the distribution of green space in the city of Surabaya, 3). Analyze the needs of green space based on area and population and thermal comfort. The study was conducted in the city of Surabaya covering $333063 \mathrm{~km} 2$, primary data from field surveys and spatial analysis with geographic information systems to identify the availability of public green spaces, types of public green spaces, large public green spaces, distribution of public green spaces, air temperature and relative humidity. Secondary data, from the city planning department, population department, and the statistical center of the city's civil registration office. The initial stage is interpreting data from Landsat 8 OLI 2018 Surabaya using ArcGIS 10.1 software. On-screen digitization is done to get the classification of land cover. To find out the spread using the fragmentation index formula while the green space needs to be analyzed using the formula area and Kakon density (2010). The results showed that the type of green space in the city of Surabaya was divided into borders $(24.4 \%)$, tombs $(0.3 \%)$, mangrove forests $(4.6 \%)$ and parks $(0.5 \%)$. GOS is distinguished by its function as an ecological, economic, social, educational and sports function. Whereas green spaces in the city of Surabaya are classified as public and private green spaces. The distribution of green space in the city of Surabaya is relatively evenly distributed in five regions, but the eastern region is dominated by mangrove forests, while the northern and western regions require additional active parks. Areas based on the needs of green space are used instead of the needs of green space based on population because based on the area produces greater needs for green space. Broader green space will have a better effect on the environment, so that green space objectives from the main ecological aspects will be achieved. The average temperature in October 2019 in the city of Surabaya was 30.7 ${ }^{\circ} \mathrm{C}$, while the relative humidity was $64.3 \%$.
\end{abstract}

Keywords: green open spaces, parks, public gardens, private garden

\section{INTRODUCTION}

Surabaya is a city experiencing rapid development in various fields such as services, trade, education, and cultures. It makes Surabaya as a city that has a lot of appeal for the surrounding population. According [1], the population around major cities will affect the Physical Indonesia Economic urban space. Urbanization resulting in population growth and an increase in physical development that ultimately led to the growing need for space. Such conditions lead to overcrowding in the city is increasing. The higher the population density will affect the needs of green open space (GOS).

GOS cities defined as the utilization and land surface is covered by elements of natural plants and planted by humans [2]. This green space can be a park, greenbelt, urban forest, reservoirs, street trees, to plant seeds and breeding sites conservation area. GOS is an elongated area or group whose use is more open, where the plants grow well that grow naturally or are deliberately planted.

In GOS public space, broadly divided into two types of parks and green space green line is an important aspect that adorn the city of Surabaya and a reflection of the city of Surabaya. GOS garden serves as a tool in the development of urban culture, education and the means of social interaction. While the city park can create beauty and comfort, absorbing pollutants from motor vehicles.

GOS is an area that must be provided by a city because it has important benefits, both ecological, economic, social, cultural and architectural [3]. According to [4], there are three benefits of green space that benefits are environmentally, socially and economically. Environmental benefits such as maintaining the stability of the climate, pollution control and conservation, and natural diversity. GOS also be used to increase the economic value of land, the means of social activities for children, adolescents, adults, and seniors, means of evacuation for emergencies, improve the microclimate, as well as increasing the oxygen reserves in urban areas[5]. While [6] convey any benefit to the mental health and physical well as social benefits. 
Green open spaces in urban green space comprised of public and private green space. Based on Spatial Planning Law No. 26 Year 2007 said that the proportion of green space of at least $30 \%$ of the area of the city, consisting of $20 \%$ GOS public and $10 \%$ private. The proportion of $30 \%$ is the minimum size to ensure ecological balance

GOS is an essential element in sustainable development. Therefore it is necessary efforts to maintain and improve the quality of the environment through the provision of adequate green open space [5]. Greening program continues to run, until the Surabaya Green and Clean program, Urban Farming, Surabaya Colored Flowers ", and increase reimplementation of the 3R (Reuse, Reduce, Recycle) in waste management.

Such programs are carried out in order to establish a healthy green city. Green environment established through activities or community-based programs / community. In addition to improving its own spacious green space through the development / revitalization of city parks, city officials are also aware that environmental quality improvements would be easier if it involves public participation.

However, along with the rapid development of the business district, industrial and vertical housing in the city, led to the growth of green space per year is less than $1 \%$.Meanwhile, the government targets a broad green space can be above $30 \%$ so that Surabaya is cool, minimal pollution, flood-free because of the infiltration, also face Surabaya become more beautiful and cool. The government is optimistic to reach $35 \%$ because of the vast green space can reduce the average air temperature in Surabaya of $34^{\circ} \mathrm{C}$ to $32-30^{\circ} \mathrm{C}$.

Automated assumption generation

One of the efforts that have been made by Surabaya city government in the management and control of public GOS. GOS is the inventory in the city of Surabaya. Due to limited human resources both in quality and quantity of the inventory is still highly tabular GOS. Besides the private GOS still inventoried whereas private green space is a potential area of public green space development to reach the amount of $20 \%$ of the area.

The purposes of this study are: 1) map the green space by identifying the type and classification of green space, 2) analyze the distribution of green space in the city of Surabaya, and 3) analyze the needs of the green space by area and population as well as thermal comfort.

\section{METHOD}

The location of this research was Surabaya City, east Java. Indonesia. Its covering $333.063 \mathrm{~km}^{2}$. Primary data were obtained from field survey and spatial analysis using GIS to identify the existing availability of public green space, the kind of public green space, public green space area, as well as its distribution. Another primary data is the air temperature and relative humidity measured at each type of land use. Secondary data were obtained from the urban planning department, department of population and civil registration statistics of the city and the central body of the city. Secondary data such as administrative map, photo imagery, spatial plan, the city of Surabaya in 2018 - 2028, legislation related to the green space, the data area and population.

Steps of Data Analysis:

1. Identification, classification and mapping GOS - carried out the collection, data collection and mapping of existing GOS Surabaya.

- Groundchecking the object of the sample at some point.

2. Analysis of ddistribution of GOSby calculating the ratio of the number of index fragmentation that region / class with the total number of map unit region.

To determine the adequacy of public green space to the needs of the public GOS, it used in Public Ratio formula:

RTH Ratio $=\frac{\text { publicgreenspacesize }}{\text { area }} \times 100 \%$

To determine the diversity of public green space by using the following formula:

$$
\text { diversity Index }=\frac{\text { numberofGOS }}{\text { totalpublicgreenspacetype }} \times 100 \%
$$

3. GOS Needs Analysis

- GOS needs by size region:

Based on the government's target of spatial planning mentioning least $35 \%$ size of the city green space, comprising $25 \%$ GOS, GOS public and $10 \%$ private.

RTHSize $=35 \%$ xextensiveterritory

- GOS needs based population:

\section{RTHSize = totalpopulationxstandard} spaciousgreenspacepercapita

- GOS needs based thermal comfort:

THI $=(0,8 \times T)+\left(\frac{\text { RHxT }}{500}\right)$.

\section{RESUlts AND DISCUSSION}

Research result shows the classification of green space in the city of Surabaya as in Figure 1 below. In this figure, it appears that the classification of the green space in the 
city of Surabaya is divided into border road and river, water parks, cemeteries and mangrove areas. The biggest green space that borders the road and the river of $86.5 \mathrm{~km} 2$, or $43.9 \%$, amounting $16,3 \mathrm{~km} 2$ mangrove forests, gardens and tombs of $1,7 \mathrm{~km} 2$ of $1,01 \mathrm{~km} 2$, the total area of green space in the city of Surabaya for $105.53697 \mathrm{~km} 2$. For more details can be seen in Table 1 .

Table 1. Size Each type of green space in the city of Surabaya in 2018

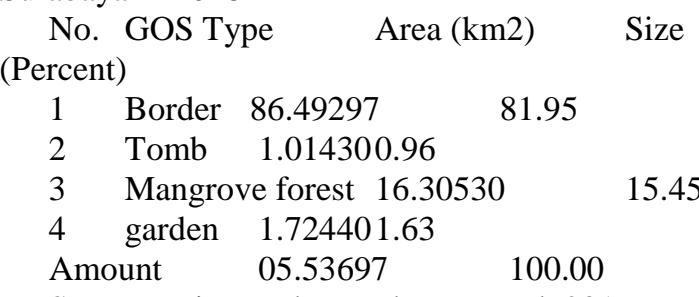

Source: Primary data and processed, 2019

From Table 1 above, it can be seen that the GOS tomb and garden have ecological functions quite large although the extent is too small. Location parks spread evenly in all regions of the city of Surabaya, while mangrove forests located along the northern coast of Surabaya. The most extensive mangrove forests located in Surabaya, east, namely mangrove Wonorejo with an area of 64.8 ha of total area of mangrove in Surabaya for 471,7 ha. This mngrove forests provide ecological functions quite large but its location away from the location of people's activities Surabaya.

Distribution of green space in the city of Surabaya evenly distributed in five regions, namely the central region, northern region, southern region, eastern and western regions. But for the mangrove forest lies only in the eastern region, or rather in the east coast city of Surabaya. Distribution of green space in the city of Surabaya basically spread evenly, but when seen from the map distribution for the narrow area is not visible due to the scale used is too small. In addition, invisibility is also influenced by the type of imagery used. Oli 8 Landsat imagery can not produce a sharp hue so that the appearance of green space classification is not visible.

Figure 1. Distribution Map of Green Open Space in Surabaya City

There were 16 GOS public [7], while in Surabaya, there are 11 kinds of TRH Public namely Taman RT, Parks RW, Park Districts, Forest City, State Parks, Streets or Media Roads, Borders Rail train, the border river, Borders roads, Border Beach (Mangrove forest), and the General Cemetery. Thus the diversity index GOS in Surabaya is 11: $16=0.6875$ or $68.75 \%$. This means that the City of Surabaya has a diversity index value at a moderate level. Size

Table 2. GOS Needs Based on Regional and Population

No Territory in Surabaya Province Area (km2) GOS need (km2) Population growth (\%) Population in $2017 \quad$ Population in 2030 GOS needs (m2)

$1 \quad$ Center $14.29 \quad 5.1765 \quad 3.42 \quad 378.473$ 585.99511 .7199 mil

\begin{tabular}{|c|c|c|c|c|}
\hline & East & 91.18 & 31.93100 .04 & 805.982 \\
\hline & 848.914 & 16,978 & $276 \mathrm{mil}$ & \\
\hline & South & 64.06 & 21.37101 .99 & 795.8 \\
\hline & 102.826 & & $20.56538 \mathrm{mil}$ & \\
\hline & North & 38,39 & 12.43652 .10 & 623.7 \\
\hline & 817.241 & 16.344 & $2 \mathrm{mil}$ & \\
\hline & West & 114.21 & 39.97350 .77 & 489.5 \\
\hline
\end{tabular}

Source: Primary data are processed, 2019

From Table 2 above. it appears that the needs of the green space by the area of better use than the GOS needs based on population, this is in accordance with the results of research [8], [9]. In general calculation is based on an area that generate greater needs than the needs of the green space based on population. GOS wider will give a better effect on the environment, thus GOS purpose of main ecological aspects will be achieved.

Another impact with respect to the broader GOS is the availability of more oxygen and carbon dioxide absorption by plants, so the air quality will be better. Better air quality will improve the health level of the population. This does not contradict the opinions [10] that DAS, as a key element of green space, a producer of oxygen that is needed by the various activities of urban life. The oxygen produced will then be consumed by humans and animals. Green function in a green open space (GOS) of the city as the 'lungs' of the city, is one aspect of the functioning of the recycling, the carbon dioxide $(\mathrm{CO} 2)$ and oxygen $(\mathrm{O} 2)$. Each 1ha green space planted with trees, shrubs, bushes and ground cover, with a surface area of $5 \mathrm{ha}, 900 \mathrm{~kg}$ able to suck $\mathrm{CO} 2$ from the air and releasing $600 \mathrm{~kg}$ of $\mathrm{O} 2$ within 12 hours [11].

Air condition in Surabaya is pretty hot with average air temperature of $28.4^{\circ} \mathrm{C}$ and relative humidity average of $82.3 \%$ is a condition that is not convenient for everyday human life. This condition can be improved to be comfortable with the planting of trees. Research [12] explains that the temperature around the area of green space (under trees shade) in Jakarta, declined $2-4^{\circ} \mathrm{C}$, microclimate and local temperatures are formed by rows of trees, showing the flow of air into the bottom of the stembantang tree the, down $10 \%-20 \%$. [13] also explains that plants, trees, shrubs and grasses can improve the city by controlling the temperature of the sun's radiation. As long as the sun is shining, the leaves can withstand solar radiation so as to lower the temperature.

Table 3. Relative Humidity and Air Temperature in Surabaya

No. Location Measurement Average Humidity (\%) The mean air temperature (oC)

1 Border $63.8 \quad 30.2$

2 fishpond $66.7 \quad 29.6$

3 Industry $60.9 \quad 32.4$

4 Settlement 62.4

5 Garden $64.9 \quad 29.8$

$6 \quad$ Water $\quad 65.9 \quad 30.4$

7 Tomb 64, $5 \quad 31.0$

8 Mangrove forest 67.8

9 Street $61.7 \quad 32.1$

Average $\quad 64.3 \quad 30.7$
31.2 

2019

Note: The measurement was carried out in October

From the above table, it can be seen that the air temperature average in October 2019 amounted to $30.7^{\circ} \mathrm{C}$, while the relative humidity of $64.3 \%$. The air temperature in October 2019 was not much different from previous years, this case indicates that the average temperature in 2019 is not much different from previous years. The same thing can happen with relative humidity, although different, but did not differ much, so for the next few years both the air temperature and relative humidity will not be changed significantly.

\section{CONCLUSIONS AND SUGGESTIONS}

The results of the research show that GOS must be qualified for being the place to gather and interact with the community and the media to reduce various types of pollution due to human activity. GOS becomes one of the important elements towards a healthy city that can prevent the decline in air quality and increasing emissions from transport / car industry, as well as being a means of entertainment and recreation which will improve the quality of life of its people. Embodiments of a healthy city requires the initiative of the municipality to conduct city development policies and programs aimed at improving the environment and public health conditions.

\section{REFERENCES}

[1] I. Ernawi, "Morfologi Transformasi dalam Ruang Perkotaan yang Berkelanjutan. Disampaikan dalam Seminar Morfologi Transformasi dalam Ruang Perkotaan yang Berkelanjutan,' Semarang, 2010.

[2] E. Bilgili, BC \& Gokyer, Urban Green Space System planning, Landscape Planning. InTech, 2012.

[3] W. Yuhong, T \& Jim, C.Y \& Haiking, “Assesing The Landscape and Ecological Quality of Urban Green Spaces in a Compact City," Landsc. Urban Plan., vol. 121, 2014.

[4] H. Atiqul, "Urban Green Spaces and an Integrative Approach to Sustainable Environment," J. Environ. Prot. (Irvine,. Calif)., vol. 2, pp. 601-608, 2011.

[5] J. \& dkk Silas, "Ruang terbuka Hijau Surabaya menuju Metropolitan yang Cerdas, Manusiawi dan Ekologis. Badan perencanaan Pembangunan Kota," Surabaya, 2014.

[6] S. Barton, Human Benefits of Green Spaces, Sustainable Landscape Series. University of Delaware, 2009.

[7] K. PU, "Pedoman Rencana tata Ruang Kota," 2013.

[8] R. Tjumardi, "Analisis Sebaran dan Kecukupan Ruang Terbuka Hijau untuk Mendukung Program Pengembangan Kota Hijau di Kabupaten Ciamis," Institut Pertanian Bogor, 2015.

[9] T. Kakon, AN \& Nobuo, M \& Kojima, S \& Yoko, “Assesement of Thermal Comfort in Respect to Building Height in a HighDensity in The Tropics," Eng. Appl. Sci., vol. 3, pp. 545-551, 2010.

[10] B. \& H. Purwantik, S \& Sasmito, “Analisis Ketersediaan Ruang Terbuka Hijau (GOS) Berdasarkan Kebutuhan Oksigen (Studi Kasus: Kota Salatiga)," Geod. Undip, vol. 3, no. 3, pp. 124-135, 2014.

[11] A. Bernatzky, "Tree Ecology and Preservation. Amsterdam," Elsevier Sci., p. 357, 1978.

[12] S. Purnomohadi, "Peran Ruang Terbuka Hijau Dalam Pengendalian Kualitas Udara di DKI Jakarta,” Institut Pertanian Bogor, 1995.

[13] L. Fracillia, "Analisis Korelasi Ruang Terbuka Hijau dan Temperatur Permukaan dengan SIG dan Penginderaan Jauh (Studi Kasus: DKI).,” 2007. 